\title{
A (COSMO)LÓGICA DAS RELAÇÕES HUMANO-ANIMAIS NAS RELIGIÕES AFRO-BRASILEIRAS
}

\author{
João Daniel Dorneles Ramos ${ }^{1}$
}

\begin{abstract}
O que me parece impressionante numa ontologia pura é até que ponto ela repudia as hierarquias [...] É o mundo da imanência. Este mundo da imanência ontológica é um mundo essencialmente anti-hierárquico [...] É a intuição de base da ontologia: todos os seres valem. A pedra, o insensato, o racional, o animal, de um certo ponto de vista, do ponto de vista do Ser, eles valem [...] (Gilles Deleuze, Cursos sobre Spinoza).
\end{abstract}

\section{Introdução}

As diferentes práticas (rituais e cotidianas) das religiões de matriz africana operam relações ${ }^{2}$ entre humanos e animais que vão além do processo de sacrifício animal. Busca-se, neste texto ${ }^{3}$, apresentar como a religião de Linha Cruzada opera modos de imanência do sagrado, seja quando animais são sacrificados e servem enquanto alimento para humanos e divindades como, também, nas diferentes passagens ${ }^{4}$ nas quais entidades (exus) possuem passagens animais ou formas destes (Exu do Lodo, Exu Morcego, etc), mobilizando intensos devires (Deleuze; Guattari, 2007) de humanos e a extra-humanos ${ }^{5}$.

Sugiro pensarmos nas relações estabelecidas e rompidas entre práticas, enunciados e formas de existência que não tomem o aspecto apenas dos humanos em detrimento das outras formas (animais, objetos, entidades etc). A Linha Cruzada é uma das formas possíveis das diferentes religiões de matriz africana e que está presente, com esta denominação, no Rio Grande do Sul. Ela agrega, no mínimo, três variações religiosas/práticas/cosmológicas, chamadas linhas: o Batuque ou a Nação (dos orixás), a Umbanda (dos caboclos, pretos-velhos e crianças - Ibejis) e a Quimbanda ou a Gira

\footnotetext{
${ }^{1}$ Universidade Federal de Pelotas e Universidade Federal do Rio Grande do Sul, Brasil.

${ }^{2}$ Estas relações se estendem também aos caboclos e caboclas da Umbanda, mas não serão aqui abordadas.

${ }^{3}$ Agradeço à Josiane Wedig pela atenta leitura realizada para os originais deste texto e à Stella Pieve por ajudar com o resumo em inglês.

${ }^{4}$ Os termos êmicos foram grafados em itálico. Palavras em itálico, contidas nas citações de autores, são grifos meus. Passagem se refere a um acontecimento ou etapa de uma determinada entidade e/ou orixá. Por exemplo, existem as passagens criança, adulto e velho de Oxalá, Iansã, Bará, etc. Bem como, existem passagens de exus (Exu Tiriri, Exu Sete Encruzilhadas, Exu Maioral, etc) e pombagiras (Maria Mulambo, Maria Padilha, Rainha, etc).

${ }^{5}$ Utilizo "extra-humanos" em sentido próximo ao entendimento daquilo que Descola, 1998 e Descola; Pálsson, 2001, falam sobre os grupos ameríndios e suas relações ecológicas e sociais com outros entes, com as alteridades. Extra-humano indica, a meu ver, a possibilidade de participação, aliança e de um agregar outros entes naturais e sobrenaturais às relações humanas/sociais/políticas/culturais.
} 
(dos exus, pombagiras, Povo Cigano e Povo do Oriente). Conforme Oro (1994: 47) o Batuque "apoia-se em elementos mitológicos, axiológicos, linguísticos e simbólicos das tradições banto e sobretudo jêje-nagô" e "seus cultos centram-se nos orixás". Já a Quimbanda "gira em torno dos Exus e das Pombagiras, entidades de intermediação entre os homens e os orixás", sendo lugares estratégicos "as encruzilhadas (cruzeiros) e os cemitérios". Para o autor, a função destas entidades é tanto abrir, como trancar "a comunicação com os deuses" (Oro, 1994: 51). Sobre a Umbanda, Oro indica que seu panteão “é formado sobretudo por espíritos de 'pretos velhos', 'caboclos' e 'ibeji' ('cosmes')". Assim, “os pretos-velhos são espíritos de negros, reais ou imaginários, que, em sua existência, foram escravos, benzedeiros, pais-de-santo"; já os caboclos são "valentes, guerreiros, insubmissos, fortes, originais donos da terra e vivendo harmonicamente com a natureza". E, por fim, os "Ibeji (Cosme e Damião - crianças) representam a pureza e a inocência" (Oro, 1994: 53-54).

Uma destas práticas rituais, o sacrifício, opera relações diferenciadas entre humanos e animais que escapam da ideia de que existem "maus tratos aos animais". Esta discussão vem à tona devido aos debates recentes, ao menos, no estado do Rio Grande do Sul, que envolvem tanto alguns membros de "defesa aos animais" como de fiéis evangélicos que buscaram estabelecer proibições ao sacrifício ritual realizado pelas religiões de matriz africana ${ }^{6}$. As relações entre humanos e animais em torno das práticas afro-brasileiras dizem respeito às possibilidades de devires (devir-animal do humano e das entidades; devir-mulher; devires-imperceptíveis) mais do que somente razões utilitárias/trocas. Este pensamento ligado às representações e racionalidades da modernidade eurocentrada, ou seja, "o paradigma dualista", nos termos de Descola e Pálsson (2001: 14), nos impede de "compreender adequadamente as formas locais do saber ecológico". Em outro trabalho, Descola (1992) aponta que, nas sociedades de natureza, plantas, animais e outras entidades pertencem a uma comunidade sociocósmica.

É seguindo o enunciado da epígrafe deste artigo que podemos compreender o empreendimento ontológico aberto nas religiões de matriz africana onde todos os entes valem. A lógica rizomática da Linha Cruzada possibilita que as diferenças, ao invés de

\footnotetext{
${ }^{6}$ Como demonstra Oro (2005), este tipo de discussão já estava presente desde os anos de 2002-2003 até o ano de 2005. Neste período, entidades "protetoras dos animais" interviram a favor de um Projeto de Lei que restringiria os sacrifícios de animais realizados pelas religiões de matriz africana -, o que se repete em 2015, como veremos.
} 
se dissolverem e unificarem, se conectem "deixando as diferenças subsistirem como tais" (Anjos, 2006: 22). Os rituais e cerimônias das linhas que nelas se operam são independentes. A Linha Cruzada produz diferenças ao mesmo tempo em que conecta diversos elementos, operando em composição da religião e da pessoa, articulando corpos e territórios. Conectar elementos é um exercício onde há fluxos. Por exemplo, a substância sangue, do animal sacrificado, agencia a relação entre pessoas, animais e a divindade que está no acutá (pedra), quando essa pedra recebe o sangue que está carregado com axé. Ocorre uma conexão nesta relação entre pessoa e extra-humanos (sangue, pedra, animal e orixá).

Para aquilo que chamamos como "objetos" há intensidades e não representações! Levando em conta o que Descola (1998: 28) afirma para o caso ameríndio, encaro o fato de que, para as religiões afro-brasileiras (que, de todo modo, está intrinsecamente ligada, isto é, cruzada aos modos de existência ameríndios), ao contrário do dualismo moderno, o cosmos é "animado por um mesmo regime cultural", fazendo com que "modos diferentes de se apreender uns aos outros" funcionem intensivamente. Segundo o autor, para irmos mais além do universalismo e do relativismo, é preciso deixar de tratar a natureza e a sociedade como substâncias antagônicas e abrir o caminho para uma compreensão na qual as entidades que compõem o que chamamos de universo possuam significado e identidade nas relações que as constituem (Descola; Pálsson, 2001) ${ }^{7}$.

Os assentamentos - acutás, ferros, plantas... - e o que é utilizado nos rituais - as vestimentas das pombagiras, a espada do Ogum, o cigarro de palha do preto-velho, o chapéu do exu, entre outros -, são operadores das relações entre humanos e extrahumanos. O assentamento do orixá é o local onde a divindade está: é a própria divindade que está ali; portanto, ele não "representa" o orixá, o acutá é o/a orixá. $\mathrm{O}$ “acutá não remete para um poder que do além se faz representar num mediador simbólico. O acutá - essa pedra sagrada aqui e agora - já carrega de imediato a totalidade do ser da divindade" (Anjos, 2008: 89). A pedra é feita (aprontada), embora ela tenha a potência orixá desde sempre: não está representando algo, ela tem vida.

Já as imagens possuem intensidades de orixás, santos católicos, caboclos, pretosvelhos, exus, pombagiras, ciganos/as, entre outras, e diferem dos acutás no aprontamento que recebem, ou seja, nos modos de ligação entre aquilo que chamamos

\footnotetext{
${ }^{7}$ Ver, outrossim, Descola, P. Par-delà nature et culture. Paris, Gallimard, 2008.
} 
de objetos e as entidades que ali existem. Enquanto um acutá precisa necessariamente receber sangue periodicamente, as estatuetas recebem sangue em algumas ocasiões. Tanto as imagens como os acutás fazem parte das conexões e encadeamentos de regimes de existência, perpassados pelas diferenciações que o conceito êmico passagem atribui.

O agenciamento de substâncias, como o sangue, e de outros elementos constituem a composição de pessoas e de outros entes. Os humanos apreendem territórios, potências, forças por meio das relações com extra-humanos que, necessariamente, também participam. Assim, com as religiões de matriz africana, estamos diante de uma "série de intrincados sistemas de classificação" que forma uma ontologia que "comporta uma metafísica e uma filosofia da natureza e da sociedade [...] Em certo sentido, o mar é Iemanjá, o raio e o vento são Iansã, e a doença é Omolu. Natureza, cultura, seres humanos, o cosmos, tudo parece articulado nesse sistema" (Goldman, 2005: 8).

Não há unificação, nem das formas, nem das forças/intensidades. Em cada linh ${ }^{8}$, alguns segmentos são acionados e outros não. As diferenças podem ser conectadas, mas não são colocadas como unidade. Há uma forma rizomática que opera “em oposição ao pensamento arborescente que caracteriza a definição de sincretismo (usual na definição das práticas religiosas africanas no Brasil)" (Anjos, 2006: 21). Portanto, o cruzamento das Linhas é pensado enquanto uma lógica na qual se produzem diferenças tanto nos âmbitos sóciocosmopolíticos como também no âmbito ontológico, em que a própria composição dos corpos e das pessoas opera-se em multiplicidade de diferenças, por meio de relações entre humanos e extra-humanos ${ }^{9}$. A Linha Cruzada mostra a existência de um sistema aberto, que potencializa corpos, pessoas, territórios e outras agências extra-humanas.

Essa lógica indica fatores do empreendimento da multiplicidade: nos sacrifícios, por exemplo, as/os umbandistas fazem "as matanças para os santos e têm as matanças para os exus: a dos Santos é num dia, e a dos exus é no outro dia”. Santos e exus são diferentes, possuem rituais e práticas distintas, mas não estão estritamente separados. Exu é o mensageiro das divindades, está na passagem, no entre-lugar. Tem o lado dos Exus, mas esse lado tem seus outros lados e faz relações com outros entes.

\footnotetext{
${ }^{8}$ Há, também, o termo similar lado (lado do jêje, lado dos exus, lado da Umbanda...).

${ }^{9}$ Para a discussão aprofundada sobre isso, ver Ramos (2015a).
} 


\section{Sacrifício e axé}

No ano de 2015 ocorreu um intenso debate sobre a questão do sacrifício ritual, no Rio Grande do Sul, principalmente, depois que um Projeto de Lei (21/2015), de autoria de uma deputada estadual, pretendia proibir o sacrifício de animais nas religiões de matriz africana. Este debate foi além do que era realizado pela e na Assembleia Legislativa, pois membros das religiões compareceram em grande número, tanto nos momentos de discussão da pauta pelos deputados e deputadas, bem como resistindo do lado de fora do prédio, conversando com a população em geral, debatendo com pessoas ligadas aos grupos de "defesa dos animais" e realizando alguns rituais ${ }^{10}$ fora e, por vezes, dentro da Assembleia Legislativa. Indico, a título de instigar o referido debate, a pergunta que José Carlos dos Anjos faz, em um dos artigos produzidos sobre a discussão:

Os sentidos ocidentais de verdade e as sensibilidades ocidentais em relação ao sofrimento, ao que é humano, o belo, o divino, continuarão a ditar a ordem do mundo sem a menor abertura em relação a possibilidade de que essa outra cultura a afro-brasileira - tenha reconhecida a condição de "maioridade" para dizer o que é válido para ela, a sua verdade humana, natural e cósmica? ${ }^{11}$.

O referido Projeto de Lei foi rejeitado pelos deputados e deputadas por conta da intensa mobilização política realizada por afro-religiosos(as), que se organizaram coletivamente, reunindo grupos que possuem suas diferenças (por exemplo: a Umbanda não sacrifica animais em seus rituais aos Caboclos e Pretos-Velhos, ao contrário do que faz o Batuque ou o Candomblé, que realiza sacrifício animal para Orixás, e da Quimbanda, que o realiza para entidades do Povo da Rua). Como ocorreu em anos

\footnotetext{
${ }^{10}$ Dentre esses: cantavam pontos da Umbanda, rezas do Batuque, evocavam Santos, Orixás e entidades diversas. Inclusive, alguns grupos afro religiosos levaram imagens de santos para dentro do prédio da Assembleia.

${ }^{11}$ Disponível em: <http://www.sul21.com.br/jornal/os-sentidos-do-sacrificio-na-religiosidade-afrobrasileira-do-nucleo-de-estudos-da-religiao-da-ufrgs/>. Acesso em: 17 de setembro de 2016.

Conferir outros links da internet referentes a este debate. Disponível em: <http://www.cartacapital.com.br/sociedade/a-hipocrisia-contra-as-religioes-africanas-foi-sacrificada793.html>. Acesso em: 17 de setembro de 2016.

Disponível em: <http://www.sul21.com.br/jornal/projeto-que-proibe-sacrificio-de-animais-em-rituais-nors-acirra-debate-entre-religiosos-e-ativistas/>. Acesso em: 17 de setembro de 2016.

Disponível em: <http://www.radioguaiba.com.br/noticia/projeto-que-proibe-sacrificios>. Acesso em: 17 de setembro de 2016.
} 
anteriores, conforme apresenta Oro (2005), afro-religiosas/os mobilizaram-se não apenas entre si, como, também, junto a outras entidades da sociedade, como Movimentos Negros.

O que estava em jogo era a proibição de um ritual realizado por segmentos da população brasileira que sempre foram e são excluídos da participação política e social do país. Assim, elites brancas, poderosas política e economicamente, queriam decidir quais práticas podem ou não ser realizadas pelos outros, em detrimento de consulta ou, ao menos, respeito às práticas religiosas e de cura de segmentos racialmente e socialmente identificados enquanto negros. Muitas vezes, as religiosidades de matriz africana não são consideradas enquanto tais: temos casos, como a IURD ${ }^{12}$, por exemplo, e outras igrejas evangélicas - e até mesmo a Igreja Católica -, que apontam na Linha Cruzada (assim como em outras religiões afro-brasileiras) a existência de "cultos demoníacos"; fazem acusações de que seus/suas adeptos/as operam "feitiçaria" e causam "maus tratos a animais" e/ou, ainda, afirmam que as práticas afroreligiosas, como um todo, são "enganação" e "charlatanismo".

Essa ativação da política, operada por parte de afro-religiosas(os), pode ser confrontada aos aparelhos de Estado e a suas diversas formas de captura (Deleuze; Guattari, 2008), que impõem normas e situações, como a proibição dos sacrifícios animais e/ou, ainda, as restrições de uso do espaço "público" para que afro-religiosos/as não coloquem suas oferendas ${ }^{13}$. No passado, muitas das práticas afro-brasileiras já foram proibidas pelo Estado, como a capoeira, o samba, as religiões afro-brasileiras, os quilombos, entre outras. Muitas dessas práticas, em outros períodos históricos, ganharam rótulos que comporiam a ideia de que o Brasil é uma Nação miscigenada, vivendo numa bela "democracia racial".

Há, sempre, a possibilidade de o Estado, mesmo o multicultural, dizimar elementos, práticas e saberes de afro-brasileiros, ameríndios e de outros coletivos. $\mathrm{O}$ que a cosmopolítica afro-brasileira (Anjos, 2006) interpela ao Estado é a possibilidade de permanência e de relação em e com territórios específicos, existenciais, e a

\footnotetext{
${ }^{12}$ Igreja Universal do Reino de Deus.

${ }^{13}$ Houve diversos posicionamentos contrários em relação aos sacrifícios animais dizendo que, tais práticas, "sujariam as ruas da cidade" expondo os animais em decomposição e de que as religiões de matriz africana matariam os animais, "grosso modo", "por matar". Estes comentários pouco ou nada falaram sobre as mortes diárias de animais para o consumo alimentar humano, largamente realizadas pelos frigoríficos e abatedouros no mundo inteiro. Ver, sobre a produção de animais para abate, a notícia disponível em: <http://agenciabrasil.ebc.com.br/economia/noticia/2016-03/ibge-diz-que-suinos-efrangos-tem-abate-recorde-em-2015>. Acesso em: 17 de setembro de 2016.
} 
possibilidade de se continuar com os atendimentos, aprontamentos, benzeduras que estes e outros coletivos humanos e extra-humanos realizam. A cosmopolítica afrobrasileira atua e mostra as intensas pluralidades de mundos: mostra às formas-Estado de pensamento e de práticas que há algo além de indivíduos em devoção; mostra que uma oferenda é mais uma relação firmada entre potências cósmicas do que um agradecimento e "um pedido de paz no final do ano".

Assim, não está em jogo ver um sincretismo festivo nas práticas da Linha Cruzada. Ela nos mostra a irrupção de intensidades e de resistências: como uma Pombagira, que destoa da forma pura de uma virgem e que resiste ao processo de ser mulher para eclodir devires, como devir-mulher e devir-povo (Povo da Rua) e, ainda, devir-minoritário (a religião afro-brasileira) e devires moleculares (de uma champagne que ela ganha numa Festa de Pombagira e de um serviço da religião feito por ela ou com sua ajuda). A cosmopolítica é um espaço de tensões em que afro religiosas/os precisam resistir aos processos opressores do Estado: aliando-se com potências extrahumanas, estes coletivos evocam outras formas de fazer política que tomam os corpos como terminais das relações com as alteridades.

As potências extra-humanas incorporam humanos. $\mathrm{O}$ sacrifício vai, intensivamente, ligar-se ao processo de composição do corpo batuqueiro e, especificamente, como modo de ativar mais as intensidades dos/as orixás, por exemplo. No processo de aprontamento que Mãe Irma $^{14}$ realizou no Batuque e que acompanhei ao longo de minha pesquisa de doutorado ${ }^{15}$, ocorreu os sacrifícios para os/as orixás, com o sangue sendo derramado um pouco na pessoa e um pouco nas vasilhas que continham os acutás, as pedras sagradas. Porque não é apenas um sangue qualquer, mas o sangue de animais específicos, que possuem um(a) orixá como dono/a. O sangue vai escorrer em partes do corpo que também têm donos/as, e os animais estão sendo imolados pelas pessoas e por orixás ${ }^{16}$. Este processo, mais do que apenas dar de comer à divindade, produz um partilhar, de uma carne e do axé entre as pessoas, entre objetos inseridos e partícipes do ato. Corrêa (1992: 108) afirma que "a imolação dos animais segue a ordem mítica dos orixás, que se inicia pelo Bará Lodê”.

\footnotetext{
${ }^{14}$ Principal interlocutora de minha pesquisa. Possui sua terreira no município de Mostardas, litoral do Rio Grande do Sul. Fez seu processo de apronte como seguimento de sua iniciação na religião.

${ }^{15}$ Entre os anos de 2011 e 2015.

${ }^{16} \mathrm{~A}$ pessoa que é mãe ou pai de santo de quem está sendo aprontado/a incorpora seu/sua Orixá no momento que faz o procedimento ritual de corte ou imolação.
} 
O animal imolado segue algumas especificidades em que são consideradas, além do tipo de animal, a cor do orixá, se este é feminino ou masculino ${ }^{17}$.Nos sacrifícios, estamos diante de forças agentivas: o sacrifício para os/as orixás, além de envolver o sangue e o animal, alimentando orixás, liga a pessoa aos acutás e opera uma potência da política cósmica. No serão ${ }^{18}$ e na festa que se realiza posteriormente, se estabelecem relações entre as pessoas e os outros entes existentes.

No aprontamento, o corpo é composto por uma teia de actantes humanos e extrahumanos (mães-de-santo, orixás, sangue, animais, ervas, pedras...) e que essa teia é traçada em intensidades específicas: no caso de Mãe Irma, o apronte que ela realizou atualizou a potência em ver, para ela poder jogar búzios e para efetivar a potência em curar, aumentando sua força em trazer o que é bom e poder tirar o ruim de outras pessoas. O aprontamento no Batuque é um dos lados que compõem os atendimentos que a mãe de santo realizará em suas funções enquanto tal. Quando a pessoa vai se iniciar e se desenvolver na religião, vemos que ocorre um processo no qual o dado e o feito, o dom e a iniciação não são separados: temos, portanto, mente e corpo operando enquanto multiplicidade. Orixás são aprontados/as quando recebem o sacrifício tanto na cabeça e no corpo da pessoa quanto na pedra, no acutá. A partir disto, orixás ocupam pessoas quando estas já estão prontas. Logo, é o axé que passa a ser ativado para ocorrer a incorporação, e é o/a orixá que é singularizado/a num momento (o apronte). Ao mesmo tempo que se faz o aprontamento no Batuque, as pessoas passam a incorporar orixás porque elas têm o dom para isso, esse dom já veio de berço e, ainda, a pessoa já começou sua iniciação (tanto na Umbanda como no Batuque).

$\mathrm{O}$ animal sacrificado será oferecido para um determinado santo. As divindades afro religiosas precisam ser alimentadas constantemente, ainda mais após o aprontamento que a pessoa faz. Esse alimento da divindade (sobretudo, as ervas e o sangue de animais) será derramado na pedra, no acutá, que é onde o santo come, tanto

\footnotetext{
${ }^{17}$ Exemplos: um galo branco é de Xangô, uma galinha amarela, é da Oxum, uma cabrita é da Iansã, um porco é do Oxóssi. Ocorre de um casal de pombos brancos serem destinados à Oxalá e Iemanjá, pois existem casos de orixás masculinos e femininos comerem na mesma ocasião.

${ }^{18}$ Serão é toda a atividade que se inicia com antecedência de uma ou duas noites de uma grande festa e, ainda, é a que se inicia a partir do processo de iniciação. Neste período, as pessoas da terreira fazem os preparativos do que será servido como alimento na festa ou ritual. Além dos sacrifícios rituais, preparamse os pratos que ficarão alimentando orixás - no caso de um aprontamento no Batuque ou de uma Roda de Batuque (cerimônia específica onde orixás chegam, ou seja, incorporam as pessoas). Para exus e pombagiras (no caso de uma festa ou apronte cruzado com a Quimbanda), preparam-se os animais sacrificados, para serem servidos a estas entidades, bem como aos humanos, no dia da festa desta linha.
} 
no momento do apronte como também ao longo da vida da pessoa iniciada (e ao longo da vida de seus/suas orixás) que estará ligada a uma terreira.

Fazer o aprontamento (algo que envolve o corpo humano, relacionado a outras agências, numa socialidade) é a cosmopolítica afro-brasileira (Anjos, 2006) no corpo. Quem é pronto deve seguir as suas obrigações (fazer sacrifício animal para orixás e, no caso de quem fez o apronte cruzado, fazer para os exus, para as pombagiras; também é reforçar a relação com caboclos da Umbanda, com orixás...), e a pessoa que se tornará mãe ou pai de santo, após a primeira ocasião de apronte, deve estar sempre preparada para receber demandas (ou seja, realizar serviços) e para aprontar mais pessoas (filhos/as), continuando os diversos acontecimentos que juntam, ao seu corpo, humano, diferentes potências extra-humanas. A pessoa vai fazendo seu aprontamento por meios de diversos reforços ao longo da vida. É, neste sentido, que o acontecimento de curar pessoas (e, também, animais ${ }^{19}$ ) e realizar sacrifícios operam cosmopolíticas.

Com o apronte e o fortalecimento dos corpos e das pessoas, o reforço, ocorrem fluxos de intensas relações: o sacrifício é realizado para orixás e é realizado, também, para a filha de santo e para outros humanos (já que a carne dos animais será consumida pelas pessoas e pelas entidades) ${ }^{20}$. Tanto as divindades quanto as pessoas absorvem o axé naquele momento. A apreensão de energias e o fortalecimento dos corpos e das relações são permeadas pela noção de que existe uma medicina nesses processos. É que não há modos de se fazer o apronte que não mobilizem as diferentes agências do Cosmos e suas relações.

Se há a lógica de apreensão do diferente, para as formas afro-brasileiras de religação com o sagrado, o comer também é muito importante. Em todas as suas festas, há sempre comida, distribuída para quem estiver presente. Quando se faz o apronte, toda a carne dos animais sacrificados vai ser consumida em uma festa posterior. A apreensão de substâncias, de territórios, de um corpo e de uma pedra (acutá) podem ser percebidas como processos que envolvem o comer. Ter um território onde se possa agir também é ter um lugar onde se pode comer. O sacrifício é realizado onde está o Santo.

\footnotetext{
${ }^{19} \mathrm{O}$ ponto das relações humano-animais nestas religiões toma outra dimensão possível: a das benzeduras. Desenvolvo isso de forma mais profunda em Ramos (2015b). Aqui, apenas indico que as mães de santo que conheço realizam diversos tipos de benzeduras em animais (sobretudo animais de grande porte no meio rural, como bezerros, porcos, ovelhas e vacas), quando estes apresentam doenças, parasitas ou problemas súbitos (como engasgos, ou quando ficam atolados na lama, etc).

${ }^{20}$ Como pondera Prandi (2001: 49), “Os orixás são parte da família, são os remotos fundadores das linhagens cujas origens se perdem no passado mítico. Em troca dessas oferendas, os orixás protegem, ajudam e dão identidade aos seus descendentes humanos".
} 


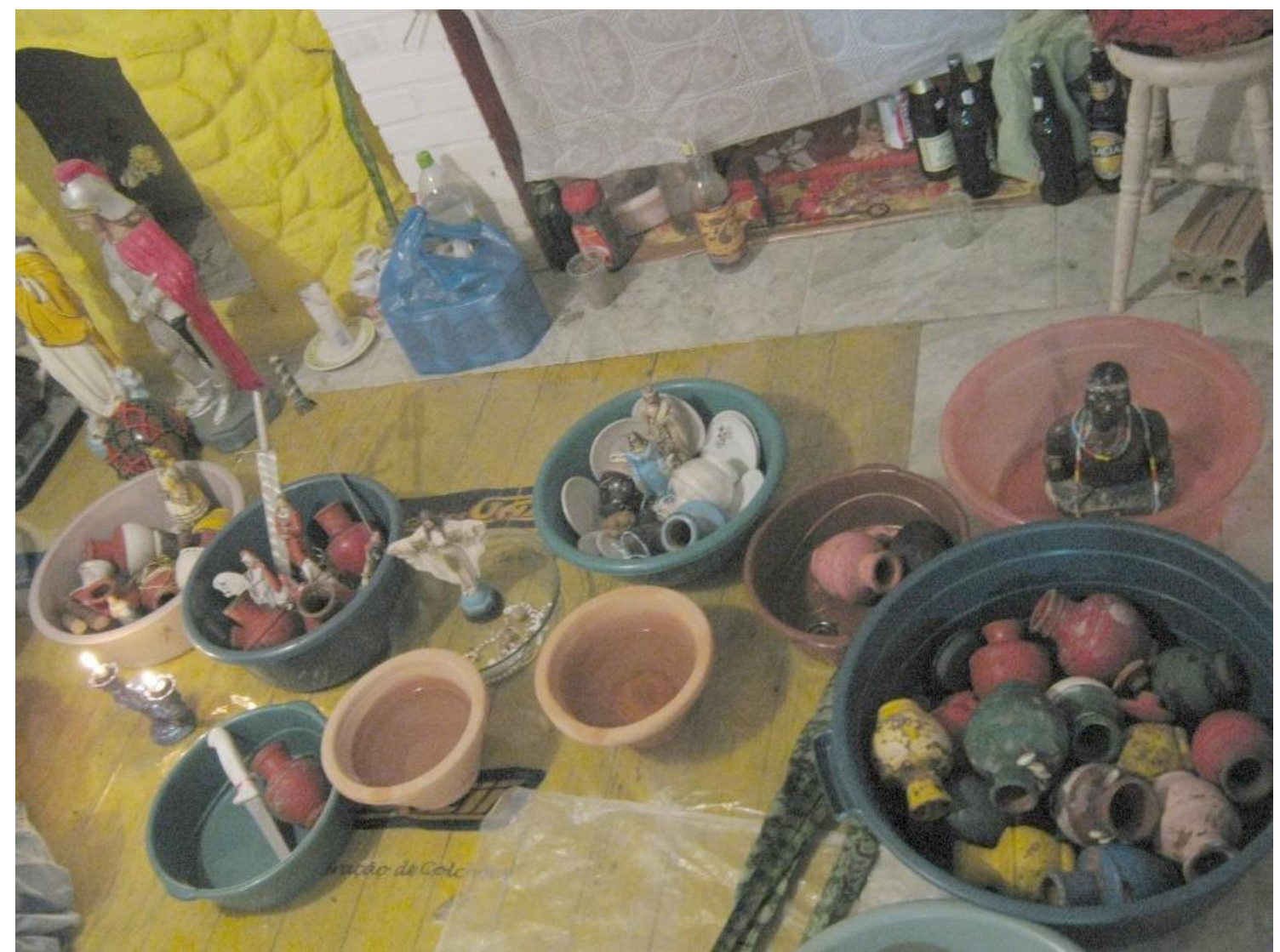

Figura 1: Bacias contendo imagens, quartinhas e outros objetos antes de receberem o sangue dos animais sacrificados para os santos. Foto do autor, julho de 2010, realizada para a pesquisa de mestrado.

Assim, a natureza, os territórios e os elementos da paisagem são conectados a outras dimensões humanas e extra-humanas. Não se trata apenas de um "cuidado" com a natureza: trata-se de uma relação intensiva entre natureza, Cosmos, pessoas, animais e seres existentes e que é operado por conectividades possívei. Conforme Oro (2005), os animais "adequados" ao sacrifício são cabras, ovelhas, porcos, galos e galinhas. Assim, outros animais, os considerados selvagens (silvestres, em extinção), os domésticos (cães, gatos, entre outros) e os de grande porte (vacas, bois e cavalos), não entram nos processos rituais de sacrifício. Como pondera um dos interlocutores deste autor, Pedro da Oxum Docô, os animais usados nos cultos afro-brasileiros são aqueles que são consumidos pelo público.

A relação intensiva agencia objetos e outras existências, operando como cosmopolítica. Constitui a diferença que difere, porque há processos nos quais os corpos são tomados pelos acontecimentos. As proteções, por exemplo, que são, geralmente, fitas de tecidos coloridos banhadas em ervas, operam como "uma infinidade de sistemas 
terapêuticos eficazes [...] que são verdadeiros sistemas conceituais e não crenças vãs" (Nathan, 2012: 114). Neste sentido, são agenciados objetos que possuem axé e que entram em relação tanto com as pessoas como com outros existentes (como os animais, as pedras, entidades, etc), em momentos rituais e cotidianos. Quando há o sacrifício de um animal, o axé do animal servirá de alimento para o orixá, e para os humanos, porque está agenciando e operando fluxos de energia. Além disso, animais e insetos pertencem $^{21}$ a orixás e fazem parte de intensas alianças entre os entes:

Rato do Bará; Tubarão da Iemanjá; Porco do Odé22 ; Capivara do Odé, da Otim e do Ossanha; Tatu do Ogum; Cachorro do Ogum e do Bará; Barata da Oiá; Lesma do Oxalá; Veado do Oxóssi [para Cristian ${ }^{23}$, Oxóssi é a ramificação, pois está junto ao Odé, a Otim e a Ossanha]; Aranha da Oxum; Rã da Oxum; Cobra Verde da Oxum; Carneiro do Xangô; Cágado, Tartaruga do Xangô (Lista elaborada a partir das informações dadas por Mãe Irma, Mãe Jalba e Cristian, em Mostardas, dezembro de 2012).

O que ocorre não é um totemismo no qual o rato, por exemplo, representa o Bará. Estamos diante de relações que intensificam o pertencimento de diversos elementos aos modos de existência no Cosmos, ou seja, o entendimento é de que determinado animal/inseto/planta/substância/etc faz parte das relações possíveis. O exercício de elencar alguns animais e insetos toma aqui o sentido de operacionalizar aquilo que potencializa as relações com orixás que vai além dos sacrifícios, pois, para as provas de orixás ${ }^{24}$ e de exus, são utilizados alguns desses extra-humanos:

Mãe Jalba ${ }^{25}$ : Já a Cobra é da Oxum. Nós fazíamos a prova do santo mas, agora, a gente não faz mais. Antigamente se fazia. Hoje, se tu mandares alguém comer um pedaço de cobra, mandam te prender! Dá cadeia. Uma [pessoa] dentro da minha $\mathrm{Casa}^{26}$ disse que chamaria a polícia [se fosse feito isso]. Hoje, a gente faz com milho torrado, com ovo quente, com pipoca, dá acará ${ }^{27} \ldots$

Cristian: Para a prova de Iansã, por exemplo, tu darias a barata para a Iansã comer, mas dá uma fritadinha na barata (risos) e não a barata crua! Mesmo assim, nos acarás, o pessoal [...] Os exus fogem bem na hora que o acará está chegando perto da

\footnotetext{
${ }^{21}$ É uma noção êmica. Nos terreiros, no quais participei na pesquisa, as pessoas dizem: o rato pertence ao Bará, a aranha pertence à Oxum. Dizer que pertence à algo é porque este participa.

${ }^{22}$ Odé é um Orixá do Batuque, companheiro inseparável de Otim, Orixá feminina. Estão presentes nas matas, estando aliados aos caboclos e animais selvagens.

${ }^{23}$ Importante interlocutor da pesquisa, de Rio Grande.

${ }^{24}$ Determinados testes realizados pela mãe ou pai de santo em pessoas da terreira, da corrente da religião.

${ }^{25}$ Outra principal interlocutora da pesquisa. Possui sua terreira no município de Rio Grande, sul do estado. Mãe de santo de Mãe Irma.

${ }^{26}$ Casa é outro modo de se referir à terreira, ao espaço ritual e religioso (templo) das religiões de matriz africana.

${ }^{27}$ Acará é uma pequena bola de algodão que, após ser molhada no dendê, é queimada e, a seguir, dada para o cavalo-de-santo (medium, pessoa que incorpora entidades, orixás, espíritos, etc) comer quando está ocupado ou incorporado.
} 
pessoa! (risos)

Mãe Jalba: E a rã é da Oxum também! E eu já comi prato de rãs, em restaurante!

Cristian: Coisa boa! Agora, tu vais dar para a pessoa aqui [na terreira], é o que ela

falou: tu vais preso! E é aquela velha história: ou tu tens [orixá, exu] ou não tens!

Porque o orixá não deixa tu veres o que estão fazendo na prova.

Mãe Jalba: E quando [a pessoa] passa em todos os testes, a gente leva no meio do salão e diz: 'apresento, aqui, fulana de tal, que passou em todos os testes. Ela está pronta para ter Casa de Religião, dirigir a Casa, assim, assim...'. Quer dizer: se ela passou nisso e tem o axé de faca, ela será dona do nariz dela.

Cristian: Depois disso, a pessoa já pode ter a sua própria Casa (Conversa com Cristian e Mãe Jalba, ocorrida em Mostardas, 06 de dezembro de 2012).

Axé de faca é quando a pessoa, no seu aprontamento, recebe de sua mãe ou de seu pai de santo, o axé para realizar sacrifícios. Portanto, fazer sacrifícios animais depende de um processo de apreensão (de aprender a fazer e de ganhar um dom) e não de simples vontade. No axé de faca a pessoa poderá realizar sacrifícios animais, ganhando inclusive facas e outros objetos no momento de seu aprontamento para isso, que dependerá muito da atuação da pessoa na religião como, também, da ação de seus/suas orixás. O dom virá de alguém ou de um(a) orixá, em momento preciso, segundo uma relação construída.

O axé está em tudo, e é por isso que o sacrifício vai além do ato de matar um animal para uma divindade: no sangue do animal, está o axé, e o contato com esse sangue é a possibilidade de apreensão de axé. Há energias presentes nos processos que se dão quando as pessoas recebem o sangue do animal no aprontamento e também há o axé que fará uma pessoa aprontar-se numa Casa, com sua mãe ou seu pai de santo e, certamente, com muitos outros actantes.

A própria noção de que o axé é vital ultrapassa os elementos tidos como "maus" e como "bons". Se compreendermos o vital como transcendência, veremos apenas o dualismo "bom ou mau", que são (e)feitos do Ocidente. Na Linha Cruzada, o bom é o elemento nomádico, são as energias que ambulam, que não se fecham. A encruzilhada mostra muito bem que os caminhos são possíveis e que são abertos. Fechar os caminhos é despotencializar as relações. Como bem lembra Anjos (2006), na religiosidade afrobrasileira, "os caminhos são percorridos por 'fluidos"” e as "energias positivas são as nômades, que não fecham um território". O nomadismo das formas está além das formas humanas, ele passa pelo território, por aquilo que denominamos como objetos, pelas pessoas, pelos espíritos... Assim, o mal "acaba sempre retornando à pessoa que o solicitou, fechando o circuito". Por isso, "a ideia de bem e mal não estão substancializadas, são formas de significação de fechamento e abertura de relações 
sociais" (Anjos, 2006: 19-20).

O axé é, portanto, um elemento vital de imanência - porque tudo são passagens, boas ou más - e tudo são caminhos possíveis, bons ou maus. A pessoa que quiser causar o mal a outra, por meios mágicos, religiosos e por práticas humanas, terá retorno com mal: a pessoa fecha o circuito da relação. Já aquela que for causar o bem, que vibrar no bem, esse bem será expandido em energias nomádicas, sem fechamento, e passará por diversos corpos, espaços, situações, etc. O bom e o mau são entendidos enquanto passagens possíveis, que se tocam, se cruzam, se potencializam e se afastam, pois não são esferas separadas e nem essências puras. O axé é vital, porque faz parte da vida e porque pode ser mobilizado em diferentes sentidos e momentos: não é uma essência pura e não é só preparado pelas pessoas.

Outro fato que nos leva a entender que axé não é uma essência, e sim sua relação no sacrifício: para se obter o axé que está no sangue do animal, esse animal terá de ser morto, mas veremos a morte do animal destinado ao sacrifício como algo mau? Ou podemos compreender que o animal não foi aleatoriamente escolhido para ser morto, simplesmente, pois o animal já tem o seu dono/a, que é um(a) orixá? É na sua morte (ou na sua passagem de planos de existência?) que o animal mobilizará o axé para a divindade - mas, mesmo em vida, o animal já mobilizava axé, em outros graus...

\begin{abstract}
O animal de quatro patas [...] não pode dar sequer um grito no instante em que será sacrificado, pois, naquele momento, ele está doando a si mesmo ao deus que irá comê-lo: se gritar, ou então se a ave bater as suas asas, o sacrifício deve ser imediatamente interrompido. Mas a sua entrega é também o efeito produzido pela força do orixá ou do exu, o desejo voraz que, partindo deles, atrai o primeiro até a cena sacrificial. $\mathrm{O}$ animal que gritasse seria como o deus que se recusa a comê-lo (Barbosa Neto, 2012: 174).
\end{abstract}

A lógica do sacrifício pode ser encarada como parte da relação cosmopolítica afro-brasileira: o animal sacrificado será comido pelas divindades, pelas entidades, mas também pelos humanos. O axé do sangue, e também da carne do animal (e o axé do animal enquanto vivente), será absorvido, no ato de comer, por todos/as actantes postos/as em relação (acutás, humanos, divindades, entidades, facas...), em diferentes graus. Orixás comem, acutás comem. Cada elemento da relação efetuada apreende a força do axé de formas diferentes: com o sangue, com a carne, com as ervas e as facas, com tudo o que está nos assentamentos... Estamos diante de participações que apreendem forças e operam relações. Sobre a noção de participação, Goldman (2012: 
279) refere que

[...] o sangue que recebo dos meus antepassados, aquele que recebo na iniciação e aquele que flui na convivência cotidiana - seja o das plantas e o dos animais consagrados ao longo dos anos no terreiro, seja o dos alimentos que compartilho nas refeições coletivas, seja simplesmente o das pessoas, divindades e espíritos com quem convivo - são, de certo ponto de vista, uma única e mesma coisa.

Mesmo o axé das ervas funciona deste modo porque, o que está sendo acionado nessa noção de apreensão e de fluxos, são as energias. Mãe Irma refere que, no lado da Umbanda, se faz o Amaci com nove ervas e produtos [fluidos prontos, também feitos com ervas] e se coloca isso na cabeça da pessoa, lava-se a cabeça dela com as ervas. Há, também, os banhos de ervas, que podem ser feitos para pessoas que não são prontas ou que não vão se aprontar na religião, pois possuem axé e são feitos por diversos motivos, como proteção, desejo em conseguir um trabalho (ou manter-se nele), firmar relações amorosas, sair de situações difíceis (desemprego, doenças, etc)...

O sacrifício também opera em sentido similar: uma pessoa pode fazer um sem precisar se aprontar na religião, por diversos motivos (cura de doenças, para conseguir um bom trabalho, para ofertar a orixás e/ou exus, pombagiras, por graças alcançadas, etc). Estas práticas sugerem a percepção de que estamos diante de espaços-tempos e devires que compõem a pessoa, os corpos diversos e os territórios. É porque toda uma política se dá nos territórios: há vários entes que participam e que vão operar a revitalização da relação entre pessoas e entidades por meio de oferendas, outros serviços e trabalhos na religião. O sacrifício é, então, uma comunicação com divindades e com outros entes para se estabelecer, ou mesmo, desfazer relações.

\section{O devir-animal e as imagens}

É preciso exercitar uma articulação entre teorias e conceitos êmicos, apreendidos a partir das vivências e experiências com a Linha Cruzada, para ser possível seguir o que afro religiosos/as fazem e tomar a religião como experiência filosófica prática e plena. Ver que existe uma experimentação de pensamento, em cada movimento da religião, é possibilitar uma potencialização política e, seguindo o que Anjos (2006: 21) indica, falaríamos de "uma forma rizomática de pensar e trabalhar as diferenças em oposição ao pensamento arborescente que caracteriza a definição de sincretismo". 
Por isso, estamos diante de devires, muito mais do que de identidades fixas. Há devires não humanos que extravasam por todos os lados os estratos antropomórficos e não possuem termo nem sujeito. Ocorrem "segmentos de devir, entre os quais podemos estabelecer uma espécie de ordem ou de progressão aparente: devir-mulher, devircriança; devir-animal, vegetal ou mineral; devires moleculares de toda espécie, devirespartículas". É que "o devir não é imitar algo ou alguém”. O devir é, a partir das formas que se tem, "do sujeito que se é, dos órgãos que se possui ou das funções que se preenche [...] extrair partículas", nas quais "instauramos relações de movimento e repouso, de velocidade e lentidão, as mais próximas daquilo que estamos em vias de nos tornar, e através das quais nos tornamos" (Deleuze; Guattari, 2007: 63-64). O devir é o movimento "pelo qual um sujeito sai de sua própria condição por meio de uma relação de afetos que consegue estabelecer com uma condição outra". Os afetos "não têm absolutamente o sentido de emoções ou sentimentos, mas simplesmente aquilo que afeta, que atinge, modifica" (Goldman, 2006: 31).

Portanto, o devir sempre remete a resistências (devir-mulher, devir-homossexual, devir-negro, devir-criança, devir-índio) e nunca pode existir devir-homem, devirheterossexual, devir-branco, devir-adulto. Ao falarmos de relação, temos de, conforme lembra Viveiros de Castro (2007: 99-100), pensar que "não se trata de "qualquer" relação. A multiplicidade é um sistema formado por uma modalidade de síntese relacional diferente de uma conexão ou conjunção de termos". É na existência da disjunção inclusiva, nos termos de Deleuze (Zourabichvili, 2004), que se dá a conexão: mas não a conexão que "prende" e por meio da qual se forma unidade e, sim, na disjunção inclusiva de diferenças que a Linha Cruzada opera, ou seja, o cruzamento. Assim, cada pessoa, sendo iniciada na religião ou não, tem seus/suas orixás. Quando ela passa a participar da religião, empreende relações com eles/elas e com caboclos/as, exus, pombagiras e outros entes. Há intensidades que se relacionam em diferentes momentos com as pessoas, com os objetos e com os animais, formando um sistema sócio-cósmico.

Estas intensidades podem ser vistas em relação às imagens, estatuetas de orixás e de entidades, que mostram, também em termos materiais, a "síntese disjuntiva". Uma imagem de gesso, antes de adentrar num terreiro e de fazer parte dele, estará com a entidade, santo, caboclo, exu, pombagira, em potência. Ou seja, ela deverá ser batizada 
num terreiro e, a partir desse batismo, ela participará das atividades que ali ocorrem e fará parte do escopo de relações possíveis. A imagem de exu, por exemplo, receberá sangue de animais sacrificados durante a sua vida, sua existência numa terreira e receberá outros elementos, como banhos de ervas, cuidados em geral, e funcionará como o encontro com as alteridades, como possibilidades de agenciamento das entidades e como compósito das relações dela (e da entidade em questão) com as pessoas e demais entes.

A imagem a seguir é de uma estatueta de Exu do Lodo. É importante salientar que essas imagens não são representações, pois é o próprio Exu do Lodo que está presentificado numa estatueta que o coloca em proximidade intensiva ao que poderíamos ver como o Diabo.

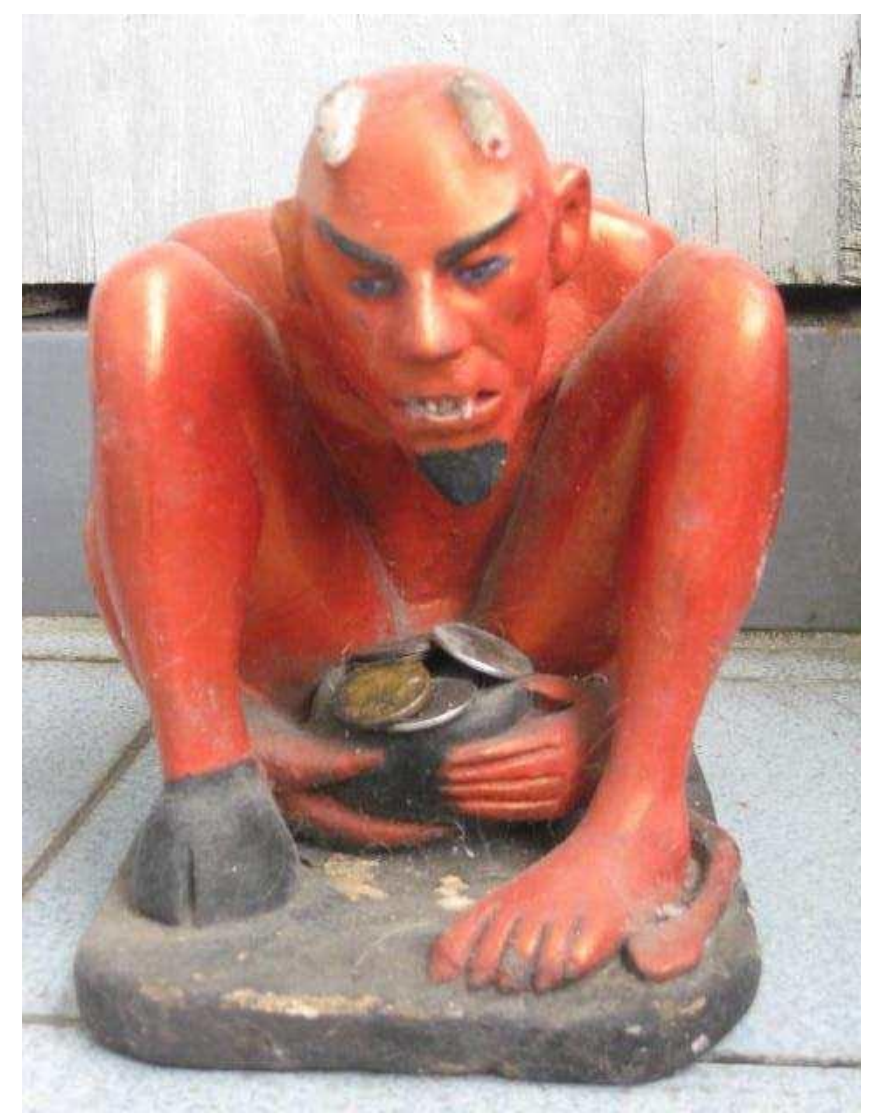

Figura 2: Exu do Lodo. Fonte: pt.wikipedia.org. Acesso em 17 de setembro de 2016.

Para complementar a questão de que não se trata de representações, remeto-me ao que Guattari (1992: 59), a partir do estudo de Marc Augé [1986] sobre o Legba, diz a respeito de que essa entidade "se instaura transversalmente" e que ele é 
[...] um punhado de areia, um receptáculo, mas é também a expressão da relação com outrem. Encontramo-lo na porta, no mercado, na praça da aldeia, nas encruzilhadas. Pode transmitir as mensagens, as perguntas, as respostas. É também o instrumento da relação com os mortos ou com os ancestrais. É, ao mesmo tempo, um indivíduo e uma classe de indivíduos, um nome próprio e um nome comum.

Guattari (1992: 59-60) indica que "o ser, a identidade e a relação com o outro são construídos", e isso "não apenas de modo simbólico mas também de modo ontológico aberto". Já Dianteill e Chouchan (2011: 76) afirmam que Legba é "inteligente, versátil e se apresenta como o restaurador do bom agenciamento do mundo" sendo "um dos seus reguladores [...]". Mas, não obstante, "Legba provoca voluntariamente contestação e desordem, ele é o 'princípio da incertitude' [...]”".

O modo "ontológico aberto" é o que deve ser apreendido para pensarmos nos entes relacionais quando estamos diante deles. Aquilo que vemos como “objetos" são, para as religiões de matriz africana, intensidades (da divindade, da entidade), que agenciam relações. Desse modo, não temos uma mera representação com uma estátua de um exu, um acutá de um Bará, com o "punhado de areia” de Legba e, nem mesmo, com uma figura impressa em papel de um santo, orixá, exu. Estátuas, pedras, imagens e outros elementos são as entidades.

Vemos que uma dimensão obscura sobre os exus foi criada não só por interpretações das suas imagens e dos cultos, mas também quando os cristãos europeus se depararam com rituais e demais relações africanas que eram realizadas com e para as divindades e outros seres que possuíam outras formas - que não as humanas. Nesse sentido,

Com a chegada do cristianismo à África, a partir do século XVI, Exu foi interpretado negativamente como um "Príapo ${ }^{28}$ negro" e seu culto considerado demoníaco. Os animais que lhe eram sacrificados foram associados ao diabo, pintado nas gravuras europeias como um ser antropomórfico (com chifres, rabo e patas de porco ou bode) ou um "cão negro". Exu "comia", em sacrifício na África, os corpos dos animais que "davam corpo" ao diabo imaginado na Europa (Silva, 2012: 1087).

\footnotetext{
${ }^{28}$ Deus grego que possui um grande falo (pênis) ereto. Sobre essa relação Exu/Príapo, ver Mourão (2012) e Prandi (2001).
} 
Cristãos trataram logo de condenar essas relações e formas, passando a divulgálas como sendo algo demoníaco, algo que não deveria ser próprio às pessoas. Isso ocorreu devido ao etnocentrismo e à moral cristã. Então, tudo aquilo que destoaria de práticas cristãs virou “coisa do demônio". Como ressalta Prandi (2001: 49), são "Príapo e Demônio, as duas qualidades de Exu para os cristãos [...] binômio pecaminoso impingido a Exu no seu confronto com o Ocidente: sexo e pecado, luxúria e danação, fornicação e maldade".

$\mathrm{Na}$ forma do Exu do Lodo, podemos ver características que o aproximam das que foram construídas sobre o diabo cristão: a pele dele é vermelha, ele possui um rabo pontiagudo e uma das pernas é de animal. Na cabeça, há duas pequenas guampas e, ainda, ele tem dentes pontudos. Próximo aos pés, ele segura um recipiente onde estão depositadas moedas. Para Mourão (2012: 157), a "função cosmológica de Èsù também abrange o comércio e sua proteção". O autor indica que, entre os iorubas, as imagens de Exu eram encontradas "na entrada de locais comerciais, em que pessoas depositavam búzios e outros tipos de moedas [...] não é incomum encontrar em algumas lojas de artigos religiosos imagens de exus e pombajiras de Umbanda exercendo a mesma função de guardiões e protetores do comércio" (Mourão, 2012: 162-163). Por sua vez, Silva (2012: 1091-1092), aponta que

[...] esses "Exus-Demônios" [...] mantêm uma continuidade com a concepção africana de Exu e diferenças em relação à concepção cristã do demônio. Considerando o papel ativo também da agência africana nesse processo de contato cultural, parece-me que o "Exu-Demônio" é muito mais africano do que sua face aparenta [...] a grande maioria faz referência aos pontos de passagem (encruzilhadas, porteiras), de intercessão entre o mundo dos vivos e dos mortos (cemitérios, catacumbas, caveiras), aos estados intermediários da matéria (lodo, lama, sombra), ou à duplicidade das coisas (sua capa é preta de um lado e vermelha de outro, como o chapéu bicolor que Exu usa). Ele é também um mediador entre distintos universos míticos e sociais, um "ser duplo" que traz em si as partes mediadas [...] "Exus-Demônios" podem fazer tanto o bem (resolver problemas de doença, justiça, falta de emprego, amorosos etc.) quanto o mal (promover separações de casal, destruir pessoas etc.). Eles fazem o que lhe pedem [...] Ou seja, Exu não "é" o diabo, e o diabo não "é" Exu, mas ambos podem estabelecer relações que ampliem seus significados originais, ao mesmo tempo em que adquirem novos significados. Se, por um lado, houve uma "demonização" do Exu africano, por outro, houve uma "exuzação" do diabo bíblico introduzindo o relativismo africano no maniqueísmo cristão do bem e do mal. 
Desse modo, pela figura de cerâmica do Exu do Lodo, são agenciadas todas as relações possíveis com esse Exu. Ele é o Exu do Lodo, ou seja, está no domínio da obscuridade e trabalha com outros seres desse domínio. Mas ele também recebe moedas e oferendas, pois exerce a função de guardião do lugar, da pessoa, e exerce proteção, assim como o Exu de Nação e o "Èsù” na África Iorubá e o Legba também fazem.

A proximidade que Exu do Lodo ganha com o diabo pode ser compreendida pelo caminho que ele guarda: estando no "intermezzo" (Deleuze; Guattari, 2007) de relações, estando naquela encruzilhada que é o lodo (que é água e é terra, que se misturam, mas que são diferenças), ele está na intermediação de formas humanas e animais (o rabo dele pode ser do diabo, mas pode ser de um touro, assim como sua pata, que é de animal, suas guampas, ao mesmo tempo, são de um bode e de um demônio...), o que lhe provoca uma parada, um instante, num devir-animal, que, segundo Deleuze e Guattari (2007: 12), "não se contenta em passar pela semelhança", pois esse devir e outros operam por "uma espécie de contrato de aliança, de pacto tenebroso [...]". Para os autores,

[...] o devir e a multiplicidade são uma só e mesma coisa. Uma multiplicidade não se define por seus elementos, nem por um centro de unificação ou de compreensão. Ela se define pelo número de suas dimensões; ela não se divide, não perde nem ganha dimensão alguma sem mudar de natureza. Como as variações de suas dimensões lhe são imanentes, dá no mesmo dizer que cada multiplicidade já é composta de termos heterogêneos em simbiose, ou que ela não para de se transformar em outras multiplicidades de enfiada, segundo seus limiares e suas portas" (Deleuze; Guattari, 2007: 33).

Exu do Lodo é a "instauração de um agenciamento" que ocorre enquanto "uma circulação de afetos impessoais, uma corrente alternativa, que tumultua tanto os projetos significantes, quanto os sentimentos subjetivos, e constitui uma sexualidade nãohumana" (Deleuze; Guattari, 2007: 12). O conceito de devir ajuda-nos a pensar que Exu está sempre num “entre", que ele efetivamente conduz uma multiplicidade de formas indiscerníveis. Devir "é um verbo tendo toda sua consistência; ele não se reduz, ele não nos conduz a 'parecer', nem 'ser', nem 'equivaler', nem 'produzir'” (Deleuze; Guattari, 2007: 19). 
Se o Exu do Lodo tem, assim como muitos outros exus e como as pombagiras, esse escopo de relações com diversos lados, eles e elas são, acredito, tomados/as por intensos devires: devires-animais, devires-partículas, devires-imperceptíveis... Para Deleuze e Guattari (2007), às relações que compõem, decompõem ou modificam um indivíduo correspondem intensidades que o afetam, aumentando ou diminuindo sua potência de agir, vindo das partes exteriores ou de suas próprias partes. Os afetos, para os autores, são devires. Por isso, existe devir-animal, sem precisarmos, necessariamente, nos tornarmos animal, um devir-mulher no homem e um devir-criança no adulto. Devir é um movimento por meio do qual é possível arrancar a identidade tida como substancial para construir outro território existencial.

\section{Devir-animal do humano e do extra-humano: algumas considerações}

Há, nos processos de preparação do ritual, uma mobilização constante de coletivos, que compõem a natureza e a sociedade para as religiões de matriz africana. Nesse sentido, os caminhos de uma cosmopolítica afro-brasileira mostram interessantes elementos de uma ética (ethos) e de uma estética. Comentando sobre o corpo do exu, Anjos (2006: 85) nos apresenta que "[a]s formas humanas em desintegração se erguem para dar vida e mistério aos complexos rituais da gira de exu”. Também, Prandi (2001: 50), vai apresentar que "Exu é aquele que tem o poder de quebrar a tradição, pôr as regras em questão, romper a norma e promover a mudança".

Ou seja, quando um exu ou pombagira eclode em toda sua forma, na qual a pessoa que o/a incorpora toma sentidos indiscerníveis, posições corporais, toda uma forma de afecção animal, o que se apresenta é a possibilidade de devir-animal do humano e, ao mesmo tempo, do ente (extra-humano), como exu, como pombagira, que devém animal - como já me disse Mãe Irma, certa vez, a pombagira é uma mulher, mas ela é exu, porque tem guampa e dentes grandes. Animal, besta, demoníaca, são as modulações que emergem das potências do povo da rua: a pombagira é o inverso da santa, ela é mulher de sete maridos, fala na cara da pessoa o que ela quer; o exu assume passagens de Maioral, de Lúcifer, de entes da noite que ambulam pelos cemitérios, as calungas, lidam com o fogo, destoam da forma humana. 


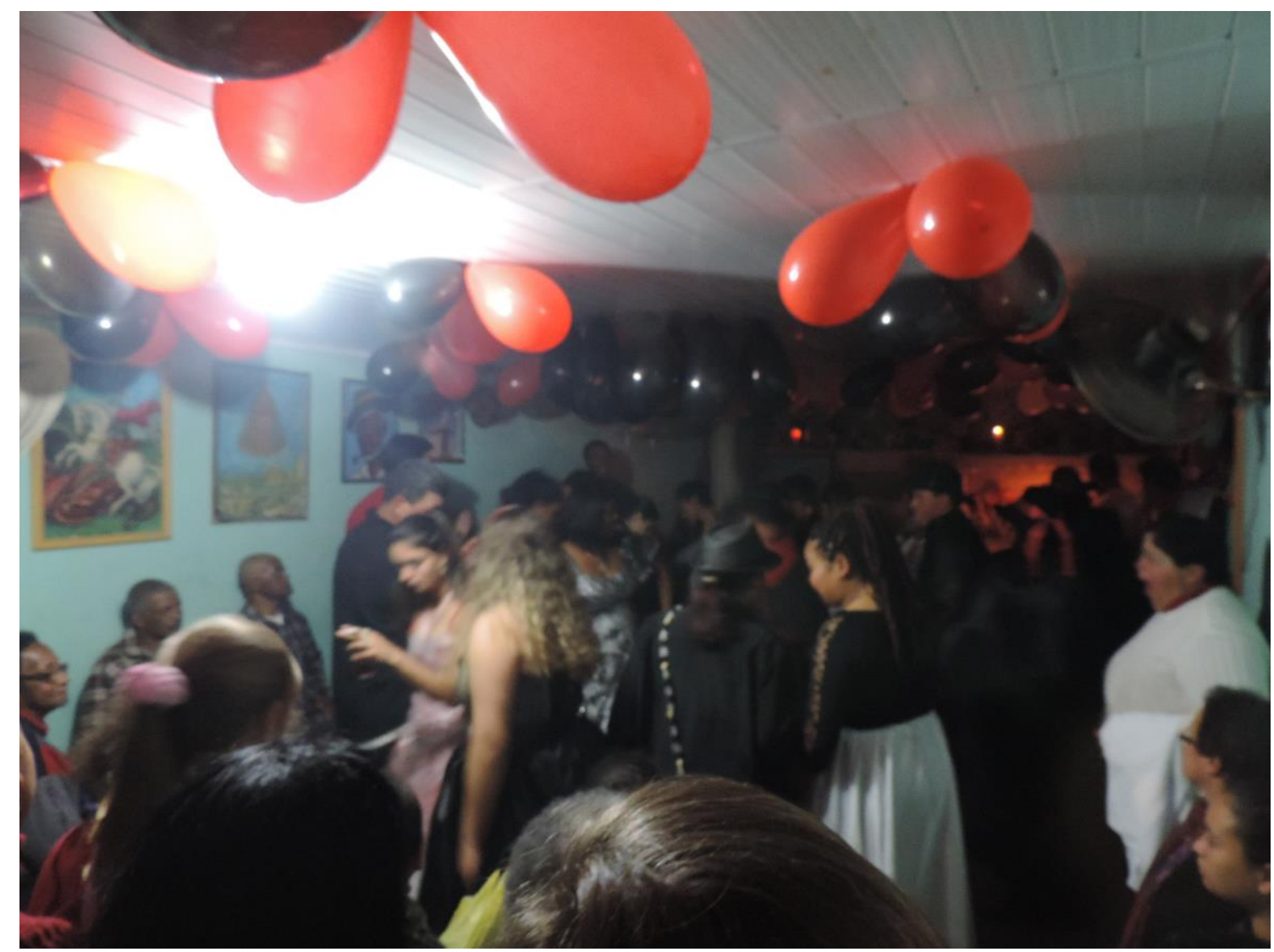

Figura 3: Exus e Pombagiras na Festa da Pombagira Sete Encruzilhadas. Foto do autor, em julho de 2016.

Não estamos na visão de rompimento com estes entes que possuem guampas, como faz a modernidade ocidental e a religiosidade cristã: está incrustado em nossa percepção eurocentrada que a humanidade deve "superar" a natureza, a bestialidade dos animais, refutar o "diabo" como mal. Em termos éticos, nas religiões de matriz africana, não há uma dimensão antagônica entre o bom e o mau, como no catolicismo, no qual "o sacrifício foi substituído pela oração e o tabu, pelo pecado, regrado por um código de ética universalizado que opera o tempo todo com as noções de bem e mal como dois campos em luta [...] (Prandi, 2001: 51). Existe uma outra forma de olhar esta animalidade/bestialidade de um exu, de uma pombagira, na qual a dimensão antropomórfica não supõe uma superação da animalidade (humana). São pelas intensidades que os entes provocam nos corpos humanos que a religiosidade afrobrasileira nos dá outra percepção acerca das relações com os animais. Mãe Irma, em outra ocasião, também já indicou que, quando seu exu, o mais brabo, chega, ela sente que seus cabelos levantam, porque são as guampas que se formam. 
Reportando-me a Anjos (2006: 86), vemos que o "ethos afro-brasileiro informa os corpos à sua volta de acordo com um arcabouço perceptivo". Assim, compreendo que, mais do que ações pragmáticas, a Linha Cruzada apresenta um mundo de intensidades no qual todos os entes valem nas percepções próprias aos modos de existência, enquanto sua diversidade de formas: no animal enquanto está vivo, que pertence a um(a) orixá; no sangue de um animal, que, num sacrifício, salva outra vida, alia-se a um corpo, para que essa outra vida crie agenciamentos individuais e coletivos na religião e fora dela (num aprontamento, a pessoa pronta poderá curar outras pessoas, realizar trabalhos na religião, etc); na carne deste animal sacrificado, que vai alimentar outros corpos e, também, entes incorpóreos, entidades, divindades, etc.

Para Espinosa (2009), Deus é a Natureza. São dois nomes para uma única e mesma coisa. Mas é um panteísmo, que expande deus(es/as) a todos os planos. A lógica do que é divino, em Espinosa, confunde-se, de certo modo, com a existência de uma imanência constante. Considero que existe uma lógica dos afetos intensivos nas religiões de matriz africana, em que diversos elementos daquilo que chamamos de natureza, sobrenatureza e cultura se imbricam numa ética, na qual os modos de ser, de existência, dos entes (humanos, pedras, plantas, entidades, espíritos, animais, sangue, etc) são perspectivas possíveis e válidas (desde que os acontecimentos, que ocorrem nos corpos, e as modulações de axé operem).

Os modos de vida da cosmopolítica afro-brasileira relacionam-se nos pluriversos (porque não dissociam natureza de cultura e porque evocam agência de entes que, a princípio, não estariam visíveis ou que seriam considerados inativos pelas concepções ontológicas ocidentais). A (cosmo)lógica das religiões de matriz africana não separa, ontologicamente, a natureza e a cultura. Se há divisões dessas dimensões, e naquelas que estabelecemos entre humano e animal, vemos que elas se dão pelos agenciamentos e pelas operações que são incluídas na lógica da diferença que a religião mobiliza. 


\section{Referências}

ANJOS, José Carlos Gomes dos. No Território da Linha Cruzada: a cosmopolítica afrobrasileira. Porto Alegre: Editora UFRGS, 2006.

A filosofia política da religiosidade afro-brasileira como patrimônio cultural africano. Porto Alegre: Debates do NER, Ano 9, número 13, p. 77-96, jan/jun, 2008.

ANJOS, José Carlos Gomes dos \& Oro, Ari Pedro. Festa de Nossa Senhora dos Navegantes em Porto Alegre. Sincretismo entre Maria e Iemanjá. Porto Alegre: Secretaria Municipal de Cultura, 2009.

BARBOSA NETO, Edgar Rodrigues. A máquina do mundo: variações sobre o politeísmo em coletivos afro-brasileiros. Tese de Doutorado em Antropologia Social. Rio de Janeiro: PPGAS/Museu Nacional/Universidade Federal do Rio de Janeiro, 2012.

CORREAA, Norton F. O Batuque do Rio Grande do Sul. Antropologia de uma religião afro-riograndense. Porto Alegre: Editora da UFRGS, 1992.

DELEUZE, Gilles. Cursos sobre Spinoza. (Vincennes, 1978-1981). Fortaleza: EDUECE, 2012.

DELEUZE, Gilles; GUATTARI, Félix. Mil Platôs: Capitalismo e esquizofrenia. Volume 4. São Paulo, Editora 34, 2007.

. Mil Platôs: Capitalismo e esquizofrenia. Volume 5. São Paulo, Editora 34, 2008.

DESCOLA, Philippe. Estrutura ou sentimento: a relação com o animal na Amazônia. Mana, Rio de Janeiro: 4 (1), 23-45, 1998.

. Par-delà nature et culture. Paris, Gallimard, 2008.

DESCOLA, Philippe. Construyendo Naturalezas: Ecología simbólica y práctica social. DESCOLA, Philippe; PÁLSSON, Gísli. Naturaleza y Sociedad: perspectivas antropológicas. México DC: Siglo XXI, 2001.

DIANTEILL, Erwan; CHOUCHAN, Michèle. Eshu, dieu d'Afrique et du Nouveau Monde. Paris: Larousse, 2011.

ESPINOSA, Baruch. Ética. Edição bilíngue tradução de Tomaz Tadeu. Belo Horizonte, Autêntica, 2009.

GOLDMAN, Marcio. Formas do Saber e Modos do Ser. Observações Sobre Multiplicidade e Ontologia no Candomblé. Religião e Sociedade, 25 (2): 102-120, 2005. letras, 2006

Como funciona a democracia. Uma teoria etnográfica da Política. Rio de Janeiro, 7

O dom e a iniciação revisitados: o dado e o feito em religiões de matriz africana no Brasil. Mana. 18(2): 269-288, 2012.

GUATTARI, Félix. Caosmose. Um novo paradigma estético. São Paulo, Editora 34, 1992.

MOURÃO, Tadeu. Encruzilhadas da cultura. Imagens de Exu e Pombajira. Rio de Janeiro: Aeroplano, 2012.

NATHAN, Tobie; STENGERS, Isabelle. Médecins et sorciers. Éditions La Découverte, Paris, 2012.

ORO, Ari Pedro (org). As religiões Afro-brasileiras do Rio Grande do Sul. Porto Alegre, EDUFRGS, 1994.

ORO, Ari. O sacrifício de animais nas religiões Afro-brasileiras: análise de uma polêmica recente no Rio Grande do Sul. Religião e Sociedade, Rio de Janeiro, v.25, n.2, 2005.

PRANDI, Reginaldo. Exu, de mensageiro a Diabo. Sincretismo católico e demonização do orixá Exu. Revista USP, São Paulo, n.50, p. 46-63, junho/agosto 2001.

RAMOS, João Daniel Dorneles. O Cruzamento das Linhas: Aprontamento e Cosmopolítica entre umbandistas em Mostardas, Rio Grande do Sul. Porto Alegre: UFRGS, 2015. 273 f. Tese (Doutorado em Antropologia Social) - Programa de Pós-Graduação em Antropologia, Universidade Federal do Rio Grande do Sul, Porto Alegre, 2015a.

A religião é como uma medicina. Aprontamento, cosmopolítica e cura entre umbandistas em Mostardas, Rio Grande do Sul. ANDRADE, João Tadeu de; MELLO, Márcio 
Luiz; HOLANDA, Violeta Maria de Siqueira (orgs.). Saúde e Cultura: diversidades terapêuticas e religiosas. Fortaleza: EdUECE, 2015 b.

SILVA, Vagner Gonçalves da. Exu do Brasil: tropos de uma identidade afro-brasileira nos trópicos. Revista de Antropologia da USP. Vol.55, número 2, 2012.

VIVEIROS DE CASTRO, Eduardo. Filiação Intensiva e aliança demoníaca. Novos Estudos, n.77, p.91-126, 2007.

ZOURABICHVILI, François. O Vocabulário de Deleuze. Rio de Janeiro: Relume Dumará, 2004.

Recebido em: 28/10/2016.

Aprovado em: 30/11/2016. 